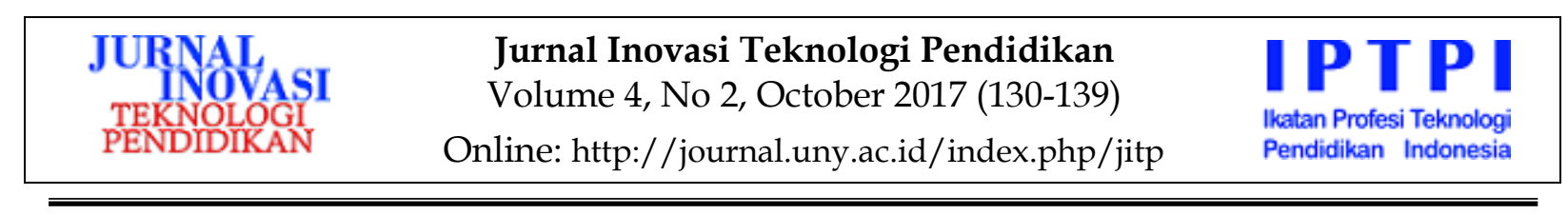

\title{
PENGEMBANGAN MULTIMEDIA PEMBELAJARAN UNTUK MENGEMBANGKAN ASPEK KOGNITIF ANAK
}

\author{
Henny Riska Pratiwi, Christina Ismaniati \\ Palm Kids School, Universitas Negeri Yogyakarta \\ hennyriska1991@gmail.com, ismaniati_fipuny@yahoo.com
}

\begin{abstract}
Abstrak
Penelitian ini bertujuan: (1) menghasilkan produk multimedia pembelajaran untuk mengembangkan aspek kognitif pada materi mengenal bilangan anak Palm Kids School Yogyakarta, dan (2) mengetahui tingkat kelayakan produk yang dikembangkan. Penelitian ini merupakan penelitian dan pengembangan yang mengacu pada langkah-langkah desain pengembangan Allesi \& Trollip, yang dikelompokkan atas tiga prosedur pengembangan, meliputi: (a) planning, (b) design, dan (c) development yang dilengkapi dengan komponen atribut mencakup standards, ongoing evaluation, dan project management. Penelitian ini menghasilkan produk multimedia pembelajaran yang memenuhi kriteria dan dinyatakan layak sebagai media pembelajaran. Skor penilaian kelayakan produk melalui uji alpha pada ahli materi adalah 3,4 (layak) dan pada ahli media adalah 3,36 (layak). Uji beta menunjukkan skor hasil penilaian guru kelas K1 sebesar 3,7 (sangat layak). Kelayakan produk multimedia pembelajaran pada peningkatan perkembangan kognitif didukung oleh peningkatan perolehan skor hasil belajar kognitif anak K1 yang diketahui dari hasil pretes dan postes anak adalah sebesar 8,7.
\end{abstract}

Kata kunci: multimedia pembelajaran, kognitif anak

\section{DEVELOPING TEACHING MULTIMEDIA TO IMPROVE THE COGNITIVE ASPECTS OF THE CHILDREN}

\author{
Henny Riska Pratiwi, Christina Ismaniati \\ Palm Kids School, Universitas Negeri Yogyakarta \\ hennyriska1991@gmail.com, ismaniati_fipuny@yahoo.com
}

\begin{abstract}
This study aims to: (1) produce learning multimedia improve the cognitive aspects of the children of Palm Kids School Yogyakarta in understanding numbers, and (2) determine the feasibility level of the developed product. This research was research and development refering to the steps of developmental design proposed by Allesi and Trollip. The design was classified into three developmental procedures including: (a) planning, (b) design, and (c) development, completed with attributes of component including standards, ongoing evaluation, and project management. This study produced teaching multimedia which meet the criteria and the product is declared feasible as teaching media based on the score of product's feasibility assessment through alpha test by material experts which is at 3.4 (feasible) and by media expert at 3.36 (feasible). Furthermore, the beta test conducted by teacher of K1 class showed the score of 3.7 (highly feasible). The product's feasibility assessment of the teaching multimedia in improving the development of cognitive aspects was supported by the score of cognitive learning outcomes of the children in K1 class was observed by pretest and post-test showing 8.7.
\end{abstract}

Keywords: teaching multimedia, children's cognitive 


\section{Pendahuluan}

Masa keemasan (golden age) pada anak usia dini ialah masa di mana stimulasi seluruh aspek perkembangan berperan penting untuk tugas perkembangan selanjutnya. Masa ini menjadi masa yang penting bagi setiap anak usia dini karena pertumbuhan otak mengalami perkembangan yang sangat cepat (eksplosif), begitu pun dengan perkembangan fisiknya. Begitu pentingnya usia dini sampai Trianto (2011, p. 14) mengungkapkan bahwa pada usia empat tahun 50\% kecerdasan telah tercapai dan $80 \%$ pada usia delapan tahun. Menurut Permendikbud No 137 Tahun 2014 perkembangan pada masa keemasan (golden age) dibagi menjadi enam aspek perkembangan yaitu: (1) nilai agama dan moral, (2) fisik-motorik, (3) kognitif, (4) bahasa, (5) sosio-emosional, (6) seni.

Permendikbud No 137 Tahun 2014 mengungkapkan standar pendidikan anak usia dini, terdiri dari: (1) belajar dan pemecahan masalah, mencakup kemampuan memecahkan masalah sederhana dalam kehidupan sehari-hari dengan cara fleksibel dan diterima sosial serta menerapkan pengetahuan atau pengalaman dalam konteks yang baru; (2) berfikir logis, mencakup berbagai perbedaan, klasifikasi, pola, berinisiatif, berencana, dan mengenal sebabakibat; (3) berfikir simbolik, mencakup kemampuan mengenal, menyebutkan, dan menggunakan konsep bilangan, mengenal huruf, serta mampu merepresentasikan berbagai benda dan imajinasinya dalam bentuk gambar. Peraturan tersebut merupakan perkembangan kognitif yang diharapkan tercapai dalam pembelajaran di pendidikan anak usia dini. Optimalisasi aspek perkembangan anak usia dini diterapkan pada kurikulum PAUD program pembelajaran TK, RA dan BA dalam bentuk pembelajaran membaca, menulis dan mengenal bilangan. Anak pertama kali diajarkan pembelajaran mengenal bilangan di taman kanak-kanak (TK) dengan rentang usia 4-6 tahun. Tujuan pembelajaran mengenalkan bilangan pada anak taman kanak-kanak adalah sebagai bekal dasar ilmu pengetahuan untuk melanjutkan ke jenjang pendidikan yang selanjutnya

Permendikbud Nomor 137 Tahun 2014 mengungkapkan capaian kemampuan yang harus dimiliki anak usia dini pada perkembangan kognitifnya mengenai konsep bilangan ialah: (1) anak mampu menyebutkan lambang bilangan 1-10, (2) menggunakan lambang bilangan untuk mengitung, (3) mencocokkan bilangan dengan lambang bilangan. Adapun cakupannya untuk mempersiapkan anak usia dini memasuki SD/MI atau bentuk lain yang sederajat. Materi mengenal bilangan merupakan bagian dari kemampuan kognitif berpikir simbolik yang perlu dioptimalkan dengan memberikan stimulasi pada materi tersebut. Stimulasi materi mengenal bilangan dapat dilakukan dengan kegiatan yang menyenangkan bagi anak-anak.

Pembelajaran mengenal bilangan dikenalkan guru Palm Kids School dengan menggunakan media poster, papan tulis dan lembar kerja anak. Menurut guru media tersebut dapat membantu mengoptimalkan perkembangan aspek kognitif anak taman kanak-kanak. Namun, pembelajaran mengenal bilangan merupakan materi yang kurang menarik untuk anak-anak Palm Kids School. Hasil observasi yang ditemukan peneliti ketika mengamati proses pembelajaran mengenalkan bilangan pada tanggal 3 Maret 2016 dengan media poster, lembar kerja dan media papan tulis ialah: (3) anak belum mampu mengurutkan bilangan 1-10 dengan benar, (2) Anak perlu bantuan guru untuk menyebutkan bilangan 1-10, (2) anak belum bisa memasangkan banyaknya objek yang dibilang dengan bilangan yang disebutnya, (2) anak bisa membilang nama bilangan dengan benar seperti, "satu, dua, tiga, empat, lima, enam", namun tidak bisa menunjuk mana lambang bilangan yang disebutnya (1) anak tidak tahu jumlah bilangan yang dihitungnya.

Hasil observasi dan pengamatan lainnya yang ditemukan peneliti di lapangan adalah anak-anak kurang berkonsen- 
trasi pada saat belajar menggunakan media pembelajaran poster, papan tulis dan lembar kerja. Beberapa anak terlihat sibuk dengan aktivitas mereka sendiri. Pada saat guru menerangkan bilangan dengan media papan tulis dua anak terlihat mencoretcoret buku dan meja, tiga anak lebih tertarik melihat gambar wallpaper dinding daripada mendengar penjelasan guru. Kemudian ada juga anak yang sering melakukan gerakan anggota tubuh ketika belajar dengan media poster. Selain itu, pada saat guru mengenalkan bilangan dengan lembar kerja pola angka terdapat beberapa anak yang menolak mengerjakan lembar kerja tersebut. Mereka lebih suka mendengarkan guru daripada menebalkan pola angka dengan lembar kerja. Permasalahan yang tampak pada hasil pengamatan tersebut media pembelajaran yang digunakan guru belum mampu memberi pemahaman pada anak serta memfasilitasi perbedaan cara belajar anak untuk bisa memahami materi bilangan. Oleh karena itu dalam pemilihan media pembelajaran untuk anak perlu memperhatikan karakteristik gaya belajar anak agar anak dapat memusatkan perhatian dalam proses pembelajaran. Pembelajaran juga sebaiknya dilakukan dengan kegiatan bermain yang menyenangkan untuk anak. permainan dengan media berbasis komputer dapat menjadi alat permainan baru untuk membantu guru dalam mengenalkan materi bilangan. Media permainan berbasis komputer untuk anak usia dini telah banyak tersedia seperti games dan multimedia pembelajaran. Pada penelitian ini media berbantuan komputer yang dimaksud adalah multimedia pembelajaran.

Adapun pemilihan multimedia pembelajaran ini berdasarkan kelebihan multimedia menurut Phillips (1997, p. 8) sebagai berikut: (1) multimedia dapat mengintegrasikan berbagai komponen seperti teks, gambar, audio, animasi dan video yang dapat membuat pembelajaran mengenal bilangan menjadi lebih menyenangkan. (2) visualisasi dengan teknologi animasi dapat memberikan informasi yang lebih nyata dari informasi yang bersifat abstrak serta menarik minat dan motivasi pengguna. (3) multimedia pembelajaran dapat memfasilitasi pengguna dengan gaya belajar yang berbeda-beda karena multimedia gabungan dari visual, suara dan gerakan sehingga mampu membantu anak belajar sesuai karakteristik gaya belajar anak. Multimedia dapat memfasilitasi perbedaan gaya belajar anak juga didukung oleh hasil penelitian Gallagher (2010, p. 85) yang memaparkan multimedia interaktif cocok digunakan untuk semua gaya belajar dan memberikan efek pemahaman kepada siswa secara individual. Maka dari itu, multimedia pembelajaran untuk mengembangkan aspek kognitif perlu dikembangkan untuk membangkitkan kegembiraan pada anak-nak dalam belajar mengenal bilangan serta mampu memfasilitasi perbedaan gaya belajar anak-anak sehingga dapat meningkatkan kemungkinan tersimpannya lebih lama konsep, pengetahuan ataupun keterampilan yang diharapkan setelah mereka belajar bilangan 1- 10 .

Selain itu, alasan lainnya yang mendukung pengembangan multimedia pembelajaran ini adalah hasil penelitian Putra \& Ishartiwi (2015, p. 177) menunjukkan multimedia pembelajaran dapat dimanfaatkan untuk mendukung proses pembelajaran anak usia dini. Pengembangan multimedia pembelajaran dalam definisi Teknologi Pendidikan merupakan aplikasi dari studi maupun praktik Teknologi Pendidikan. Pengembangan ini memadukan elemen Teknologi Pendidikan secara eklektik, yaitu elemen Study, Ethical practice, Facilitating, Learning, Improving, Performace, Creating, Using, Managing, Appropriate, Processes, dan Resources (Januszewski \& Molenda, 2008, p. 1). Dimana pengembang melakukan analisis kebutuhan sebagai salah satu sumber informasi untuk mengetahui permasalahan serta mencari solusi dari masalah tersebut sehingga pembelajaran menjadi lebih bermakna dan student centered. Improving yang diharapkan dari penelitian pengembangan ini adalah multimedia pembelajaran dapat membantu 
guru menstimulasi perkembangan kognitif anak K1 pada materi bilangan sehingga pada akhirnya menuju pencapaian kemampuan kognitif yang optimal. Multimedia pembelajaran untuk mengembangkan aspek kognitif dilandasi beberapa teori dalam pengembangannya, diantaranya: penggunaan tipografi, musik dan warna pada multimedia pembelajaran. Tipografi pada multimedia pembelajaran digunakan pada saat memilih jenis huruf untuk teks yang ditujukan untuk multimedia pembelajaran anak usia dini. Menurut Wijaya (2016, p.4) huruf yang digunakan sebaiknya adalah huruf yang bentuknya sederhana dan mudah dibaca. Oleh karena itu pengembang menggunakan jenis font Comic Sans sebagai jenis huruf yang digunakan dalam multimedia pembelajaran. Font Comic Sans memiliki jenis bentuk lekukan yang terlihat jelas namun tidak formal. Jenis font ini memberikan kesan menyenangkan dan mudah dibaca anak-anak.

Selanjutnya, penggunaan musik dalam komponen pengembangan multimedia pembelajaran. Musik berfungsi untuk merangsang/stimulan, memusatkan perhatian, membangun emosi yang senang serta dapat meningkatkan hasil belajar secara sadar atau tidak sadar kepada anak (Deporter, Reardon \& Singer, 2010, p.110). Musik yang digunakan pengembang dalam komponen multimedia pembelajaran untuk mengembangkan aspek kognitif adalah musik yang menggembirakan dengan irama tempo irama sedang.

Penggunaan warna dalam pengembangan multimedia pembelajaran juga merupakan salah satu hal penting yang turut menentukan kelayakan sebuah program paket multimedia. Warna dapat meningkatkan kreativitas dan kemampuan mengingat anak. Oleh sebab itu penggunaan warna yang tepat pada pembelajaran usia dini khususnya usia 4-5 tahun sangat penting bagi perkembangan kognitifnya (Wahyuningsih, 2011). Pendapat tersebut juga didukung oleh Sulasmi (2002, p.41) yang mengungkapkan warna muda/terang adalah warna yang lebih disarankan digunakan dalam proses pembelajaran untuk anak karena dapat merangsang kreativitas, memberi semangat, memengaruhi rasa estetika, memperkuat daya imajinasi, dan memperkuat rangsangan motorik anak.

Maka dari itu dalam mengembangkan multimedia pembelajaran pengembang menggunakan kombinasi warna-warna cerah/terang yang disukai anak seperti warna biru muda kombinasi dengan warna orange sebagai tampilan opening, hijau pucat kombinasi dengan coklat sebagai background tampilan multimedia pembelajaran sehingga tampilan multimedia pembelajaran memberikan kesan ceria pada anak-anak.

Berdasarkan pemaparan tersebut tujuan penelitian pengembangan ini adalah menghasilkan multimedia pembelajaran yang layak untuk anak K1 Palm Kids School Yogyakarta dan mengetahui adanya peningkatan aspek kognitif pada anakanak Palm Kids School Yogyakarta.

\section{Metode Penelitian}

Penelitian ini menggunakan model penelitian pengembangan atau Research and Development (R\&D) yang diadaptasi dari model pengembangan multimedia pembelajaran menurut Alessi \& Trollip (2001, p. 134). Adapun bagan langkah-langkah penelitiannya disajikan pada Gambar 1.

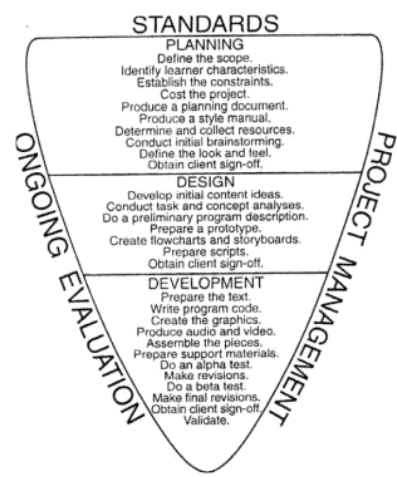

Gambar 1. Langkah Penelitian Alessi \& Trollip

Penelitian ini menggunakan pendekatan kualitatif dan kuantitatif. Data kua- 
litatif didapat dari analisis kebutuhan anak K1 Palm Kids School Yogyakarta yang digunakan untuk kepentingan pengembangan produk. Data kuantitatif didapat dari ahli media dan ahli materi (uji alpha) juga dari anak dan guru (uji beta). Data tersebut dibutuhkan agar nantinya dapat memberikan gambaran mengenai kelayakan multimedia dan kualitas teknik tampilan produk serta peningkatan perkembangan kognitif anak setelah menggunakan produk media pembelajaran ini.

Penelitian ini dilakukan di Kindergarten Palm Kids School Yogyakarta. Adapun waktu penelitiannya adalah mulai dari bulan Maret sampai dengan Mei tahun 2016. Subjek atau responden yang terlibat dalam penelitian ini adalah anak K1 Palm Kids School Yogyakarta yang terdiri dari 22 anak K1 yang dibagi menjadi 2 kelompok yaitu 11 anak K1 pagi yang menggunakan multimedia pembelajaran dan 11 anak K1 siang yang belajar tampa multimedia pembelajaran. Subjek untuk uji coba tes alpha dilakukan oleh ahli materi dan ahli media yang terdiri dari 2 Ahli Materi dan 2 Ahli Media. Sedangkan untuk subjek uji coba tes beta dilakukan oleh 1 head teacher K1 Palm Kids School Yogyakarta.

Prosedur pengembangan yang dilakukan meliputi tahap perencanaan (planning), desain (design), pengembangan (development). Pada tahap perencanaan meliputi analisis kebutuhan, identifikasi bidang/ruang lingkup materi, identifikasi karateristik anak, penentuan dan pegumpulan sumber dan melakukan brainstorming.

Pada tahap desain meliputi mengembangkan konsep awal, menganalisis konsep dan tugas, pembuatan flowchart, menentukan desain tampilan, menentukan software serta melakukan evaluasi dan revisi. Pada tahap pengembangan meliputi penyiapan teks, memproduksi narasi, gambar, animasi, audio dan video. Menggabungkan bagian, menyiapan materi pendukung, melakukan uji alpha kepada 2 orang ahli media dan 2 orang ahli materi, melakukan revisi, melakukan uji beta ter- hadap 1 head teacher K1, membuat revisi akhir, dan melakukan uji program multimedia pembelajaran kepada 11 anak K1 Palm Kids School Yogyakarta.

Data penelitian diperoleh dari lembar pre-test dan post-test, lembar penilaian ahli media dan materi, lembar penilaian anak serta lembar penilaian guru. Lembar penilaian pre-test dan post-test berbentuk soal mencocokkan gambar dengan angka dan mengurutkan pola angka. Lembar penilaian ahli, lembar penilaian anak dan lembar penilaian guru bentuk checklist sehingga praktis dalam pelaksanaannya. Sedangkan instrumen yang diberikan pada anak, akan dikembangkan peneliti dalam bentuk kuesioner sederhana. Jawaban dari pertanyaan dalam instrumen berupa $5 \mathrm{ka}$ rakter emoticon yang nantinya akan dijawab oleh anak-anak setelah menggunakan multimedia pembelajaran dengan arahan dari guru pendamping.

Data yang diperoleh melalui angket dari ahli materi, ahli media, dan tanggapan anak terhadap produk multimedia pembelajaran yang dikembangkan kemudian dianalisis dengan tabel konversi nilai yang diadaptasi dari Sukardjo (2006, pp. 151152).

Tabel 1. Konversi Rata-Rata Skor Menjadi Kriteria

\begin{tabular}{lll}
\hline Kriteria & $\begin{array}{l}\text { Interval } \\
\text { Rerata skor }\end{array}$ & Kriteria \\
\hline $\begin{array}{l}\text { Sangat baik } \\
\text { Baik }\end{array}$ & $\begin{array}{l}3,4<\mathrm{X} \\
2,8<\mathrm{X} \leq 3,4\end{array}$ & $\begin{array}{l}\text { Dapat dijadikan contoh } \\
\text { Dapat digunakan tanpa } \\
\text { perbaikan }\end{array}$ \\
Cukup baik & $2,2<\mathrm{X} \leq 2,8$ & $\begin{array}{l}\text { Dapat digunakan dengan } \\
\text { sedikit perbaikan }\end{array}$ \\
Kurang & $1,6<\mathrm{X} \leq 2,2$ & $\begin{array}{l}\text { Dapat digunakan dengan } \\
\text { banyak perbaikan }\end{array}$ \\
\hline
\end{tabular}

Peningkatan perkembangan kognitif anak dalam materi mengenal bilangan dapat diketahui dengan membandingkan nilai post-test dan nilai pre-test. Jika nilai post-test menunjukkan skor lebih tinggi dari pada nilai pre-test pada subjek penelitian setelah diberikan perlakuan dengan menggunakan multimedia pembelajaran. Maka 
multimedia pembelajaran dikatakan berpengaruh untuk mengoptimalkan perkembangan kognitif anak K1 dalam materi mengenal bilangan. Setelah menganalisis hasil eksperimen peneliti membuat kesimpulan berdasarkan uji statistik untuk mengetahui apakah hipotesis diterima atau ditolak. Uji statistik yang digunakan adalah Independent sample t-test dengan software SPSS 16.0. Pemilihan uji statistik Independent sample ttest berdasarkan hipothesis penelitian yang berbentuk komparatif dengan dua sampel independen (Sugiyono, 2010, p. 27).

\section{Hasil Penelitian dan Pembahasan}

Hasil penelitian meliputi kegiatan uji coba setelah pengembangan multimedia pembelajaran. Uji coba penelitian yang dilakukan pada pengembangan multimedia pembelajaran ini meliputi uji alpha dan uji beta. Uji alpha dilakukan masing-masing oleh 2 orang ahli media dan 2 orang ahli materi, sedangkan uji beta dilakukan oleh 11 anak taman kanak-kanak K1 Palm Kids School Yogyakarta. Ahli media mengevaluasi multimedia pembelajaran dari aspek media dan ahli materi mengevaluasi dari aspek materi dan isi. Hasil evaluasi dari ahli media dan materi akan dijadikan bahan untuk melakukan revisi multimedia pembelajaran.

Setelah dilakukan revisi terhadap hasil evaluasi uji alpha kemudian dilanjutkan dengan melakukan uji beta. Hasil uji beta dijadikan acuan hasil pengembangan multimedia pembelajaran yang dikategorikan layak untuk digunakan pada pembelajaran. Pembahasan hasil validasi dari ahli materi dan ahli media dijelaskan sebagai berikut.

\section{Analisis Data Uji Alpha}

Hasil validasi yang dilakukan oleh ahli media 1 diperoleh rata-rata penilaian yakni 3,2 dengan kategori "Baik" dan dinyatakan "Layak" serta dapat dilakukan uji coba berikutnya. Hasil penilaian oleh ahli media 2 diperoleh rata-rata penilaian 3,52 dengan kategori "Sangat Baik" dan dinyatakan "Layak" serta dapat dilakukan uji coba berikutnya. Hasil analisis data penilaian oleh kedua ahli media dapat dilihat pada Tabel 2.

Tabel 2. Rerata Skor Hasil Validasi Ahli Media

\begin{tabular}{lcccl}
\hline \multirow{2}{*}{ Aspek Penilaian } & \multicolumn{2}{c}{ Skor Ahli } & & \\
\cline { 2 - 3 } & \multicolumn{2}{c}{ Media } & Rerata & Kategori \\
\cline { 2 - 3 } Tampilan Program & 3,1 & 3,2 & 3,2 & Baik \\
Ketepatan Program & 3,3 & 3,8 & 3,6 & $\begin{array}{l}\text { Sangat } \\
\text { Jumlah }\end{array}$ \\
Rata-rata & 80 & 88 & 84 & \\
& 3,2 & 3,52 & 3,36 & Baik \\
\hline
\end{tabular}

Selanjutnya hasil validasi oleh ahli materi 1 terhadap seluruh aspek yang divalidasi diperoleh rata-rata penilaian sebesar 3,1 dengan kategori "Baik" dan dinyatakan layak untuk diujikan pada tahap berikutnya. Penilaian ahli materi 2 terhadap seluruh aspek yang divalidasi diperoleh rata-rata penilaian sebesar 3,7 dengan kategori "Sangat Baik" dan dinyatakan "Layak" atau sudah siap untuk diujikan pada tahap berikutnya. Penilaian dua ahli materi dapat dilihat pada Tabel 3.

Tabel 3. Rerata Skor Hasil Validasi Ahli Materi

\begin{tabular}{|c|c|c|c|c|}
\hline \multirow{2}{*}{ Aspek Penilaian } & $\begin{array}{l}\text { Skor } \\
\text { Materi }\end{array}$ & Ahli & \multirow[t]{2}{*}{ Rerata } & \multirow[t]{2}{*}{ Kategori } \\
\hline & 1 & 2 & & \\
\hline Materi Program & 3,1 & 3,8 & 3,5 & $\begin{array}{l}\text { Sangat } \\
\text { Baik }\end{array}$ \\
\hline $\begin{array}{l}\text { Ketepatan Program } \\
\text { Jumlah }\end{array}$ & $\begin{array}{l}3,1 \\
74\end{array}$ & $\begin{array}{l}3,6 \\
87\end{array}$ & $\begin{array}{l}3,4 \\
84\end{array}$ & Baik \\
\hline Rata-rata & 3,1 & 3,7 & 3,4 & $\begin{array}{l}\text { Sangat } \\
\text { Baik }\end{array}$ \\
\hline
\end{tabular}

Berdasarkan analisis terhadap hasil validasi kedua ahli materi dan ahli media dapat disimpulkan bahwa kualitas Multimedia pembelajaran untuk mengembangkan aspek kognitif termasuk kategori "Baik" dan dinyatakan "Layak" untuk diujikan pada tahap berikutnya.

\section{Analisis Data Uji Beta}

Uji beta atau tes beta merupakan tes akhir yang sepenuhnya dilakukan oleh 
Head teacher dan anak K1 untuk mengukur peningkatan perkembangan kognitif setelah belajar menggunakan multimedia pembelajaran. Uji beta dilakukan secara bertahap sebanyak 3 kali pertemuan. Peserta yang melakukan uji beta berjumlah $1 \mathrm{Head}$ teacher K1, 11 anak K1 pagi dan 11 anak K1 siang Palm Kids School Yogyakarta. Berikut Tabel 4 hasil rekapitulasi data validasi uji beta Head teacher K1 Palm Kids School Yogyakarta.

Tabel 4. Hasil Uji Beta Head Teacher K1 Palm Kids School

\begin{tabular}{lcl}
\hline Aspek Penilaian & Penilaian & Kriteria \\
\hline $\begin{array}{l}\text { Kejelasan Tujuan } \\
\text { Belajar }\end{array}$ & 2 & Cukup baik \\
$\begin{array}{l}\text { Kejelasan Materi dan } \\
\text { Petunjuk }\end{array}$ & 4 & Sangat Baik \\
$\begin{array}{l}\text { Respon Jawaban Yang } \\
\text { Benar }\end{array}$ & 4 & Sangat Baik \\
$\begin{array}{l}\text { Respon Jawaban Yang } \\
\text { Salah }\end{array}$ & 4 & Sangat Baik \\
$\begin{array}{l}\text { Kesesuaian } \\
\text { Kemudahan }\end{array}$ & 3 & Baik \\
$\begin{array}{l}\text { Penggunaan } \\
\text { Kejelasan Jenis Huruf }\end{array}$ & 3 & Baik \\
$\begin{array}{l}\text { Kombinasi Warna } \\
\text { Kualitas Gambar }\end{array}$ & 4 & Sangat Baik \\
Kualitas Fisik & 4 & Sangat Baik \\
Multimedia & 4 & Sangat Baik \\
\hline Jumlah & 40 & \\
\hline Rata-rata & 3,7 & Sangat Baik \\
\hline
\end{tabular}

Berdasarkan hasil uji beta Head teacher K1 Palm Kids School Yogyakarta pada program multimedia pembelajaran untuk mengembangkan aspek kognitif diperoleh rata-rata 3,7 dengan kategori sangat "Baik" dan dinyatakan "Layak" untuk digunakan dalam proses pembelajaran materi mengenal bilangan 1-10.

Sebelum uji peneliti juga melakukan pengamatan terhadap reaksi dan sikap anak anak K1 setelah menggunakan multimedia pembelajaran melalui instrumen yang terdiri dari 5 pertanyaan. Tabel penilaian terhadap respon dan tanggapan anak K1 setelah menggunakan multimedia pembelajaran dapat dilihat pada Tabel 5 .

Uji beta selanjutnya juga sebagai evaluasi sumatif dilakukan untuk menge- tahui peningkatan pekembangan kognitif anak K1 setelah menggunakan multimedia pembelajaran. Evaluasi dilakukan dalam bentuk pre-test dan post-test. Pre-test dilakukan pada pertemuan awal yakni pada tanggal 5 Mei 2016 sebelum siswa memperoleh materi menggunakan multimedia pembelajaran.

Tabel 5. Hasil Respon dan Tanggapan Anak K1

\begin{tabular}{lll}
\hline Aspek yang divalidasi & $\begin{array}{l}\text { Rata- } \\
\text { rata }\end{array}$ & Kriteria \\
\hline Tampilan Menarik & 3,55 & Sangat Baik \\
Musik Menarik & 3,27 & Baik \\
$\begin{array}{l}\text { Kesesuaian Materi } \\
\text { Dengan Tujuan }\end{array}$ & 3,81 & Sangat Baik \\
$\begin{array}{l}\text { Kemenarikan Warna } \\
\text { Peningkatan Motivasi }\end{array}$ & 3,5 & Sangat Baik \\
Belajar & 3,81 & Sangat Baik \\
\hline Rata-rata & 3,59 & Sangat Baik \\
\hline
\end{tabular}

Post-test dilakukan pada 2 kali pertemuan yakni pada tanggal 18 dan 26 Mei 2016 setelah anak belajar menggunakan multimedia pembelajaran. Pre-test dan posttest diberikan kepada anak K1 kelas pagi dan siang di Palm Kids School Yogyakarta. Pre-test dan post-test pertama diberikan kepada anak K1 pagi sebagai subjek uji coba penggunaan multimedia pembelajaran.

Sedangkan, pre-test dan post-test yang diberikan kepada subjek uji coba anak kelas $\mathrm{K} 1$ siang berfungsi sebagai kelas kontrol atau kelas yang tidak diberi perlakuan multimedia pembelajaran dalam materi mengenal bilangan 1-10. Adapun perbandingan perkembangan hasil belajar kognitif anak K1 pagi dan siang yang diperoleh melalui pre-test dan post-test dapat dilihat pada Tabel 6 .

Tabel 6. Skor Hasil Pre-test dan Post-test Anak K1

\begin{tabular}{lllll}
\hline \multirow{2}{*}{$\begin{array}{l}\text { Subjek } \\
\text { Uji coba }\end{array}$} & \multicolumn{2}{l}{$\begin{array}{l}\text { Kelas Multimedia } \\
\text { (K1 Pagi) }\end{array}$} & \multicolumn{2}{l}{$\begin{array}{l}\text { Kelas Kotrol } \\
\text { ( K1 Siang ) }\end{array}$} \\
\cline { 2 - 5 } Pretest & Posttest & Pretest & Posttest \\
\hline $\begin{array}{l}\text { Nilai } \\
\text { Tertinggi }\end{array}$ & 9,4 & 9,7 & 9 & 10 \\
$\begin{array}{l}\text { Nilai } \\
\text { Terendah }\end{array}$ & 2 & 6 & 4 & 3 \\
\hline Rerata & 6.8 & 8.7 & 5.4 & 5.6 \\
\hline
\end{tabular}


Hasil pre-test dan post-test antara kedua kelas tersebut kemudian diuji statistik menggunakan uji Independen t-test dengan taraf signifikansi (a) 0,05. Rekapitulasi hasil uji statistik disajikan pada Tabel 7.

Tabel 7. Hasil Uji T

\begin{tabular}{llll}
\hline $\begin{array}{l}\text { Subjek Uji } \\
\text { Beda }\end{array}$ & $\begin{array}{l}\text { Hasil } \\
\text { Uji T }\end{array}$ & $\begin{array}{l}\text { Nilai } \\
\text { Sig }\end{array}$ & Keterangan \\
\hline $\begin{array}{l}\text { Kelas } \\
\text { Multimedia }\end{array}$ & 3.387 & 0.03 & $\begin{array}{l}\text { Signifikan } \\
\text { Kelas Kontrol }\end{array}$ \\
0.981 & 0.342 & $\begin{array}{l}\text { Tidak } \\
\text { Signifikan }\end{array}$ \\
\hline
\end{tabular}

Berdasarkan hasil uji-t di atas diketahui bahwa nilai Sig < (a) 0.05 sehingga dapat disimpulkan Ho ditolak dan dapat disimpulkan hipotesis penelitian dinyatakan diterima. Berdasarkan hipotesis tersebut, maka terjadi peningkatan atau perkembangan kognitif pada anak K1 pagi Palm Kids School Yogyakarta setelah belajar dengan multimedia pembelajaran untuk mengembangkan aspek kognitif.

Berdasarkan kajian di atas dapat disimpulkan multimedia pembelajaran mampu menjadi salah satu media pembelajaran yang digunakan guru untuk menstimulasi perkembangan kognitif anak K1 sehingga perkembangan kognitif anak K1 menjadi optimal pada materi mengenal bilangan 1-10.

Hasil kajian di atas juga menguatkan pendapat Edgar Dale (Munir, 2013, p. 260) bahwa gambar dalam multimedia pembelajaran dapat mengubah pesan verbal kepada tahap lambang visual yang membuat pembelajaran lebih menarik dan efektif.

Multimedia pembelajaran untuk mengembangkan aspek kognitif menggunakan teks, animasi, warna, narasi serta musik dalam proses menyampaikan informasi kepada anak K1. Penggunakan teks, animasi, warna, narasi serta musik dalam proses pembelajaran mengenal bilangan 110 dapat meningkatkan minat dan motivasi anak dalam proses pembelajaran.

Penelitian ini memperkuat pendapat Phillips (1997, p. 11) mengenai ke- lebihan multimedia pembelajaran dimana salah satu kelebihan multimedia pembelajaran mampu mempengaruhi minat dan motivasi pengguna. Penelitian ini juga menguatkan beberapa penelitian sebelumnya seperti penelitian Tsung (2012, p. 47) yang mengemukakan bahwa kelebihan multimedia pembelajaran mampu menampilkan gambar dan suara yang menarik perhatian anak sehingga anak tidak mudah bosan dan merangsang motivasi belajar anak serta hasil penelitian Putra \& Ishatiwi (2015, p. 177) yang menunjukkan multimedia pembelajaran dapat dimanfaatkan sebagai salah satu media pembelajaran yang digunakan untuk men-dukung proses pembelajaran anak usia dini.

Penelitian Kalyuga \& Liu (2015, p. 4) memaparkan manfaat multimedia pembelajaran dapat memberi ruang gerak anak untuk aktif membangun pengetahuan mereka. Selain itu, penelitian ini juga mendukung pendapat Sulasmi ( 2002, p. 41) yang mengungkapkan penggunakan warnawarna cerah dalam multimedia pembelajaran dapat memperkuat rangsangan semangat, daya imajenasi dan motorik anak.

\section{Simpulan dan Saran}

Produk multimedia pembelajaran untuk mengembangkan aspek kognitif merupakan salah satu media pembelajaran yang dapat digunakan untuk membantu anak taman kanak-kanak belajar mengenal bilangan 1-10. Multimedia pembelajaran ini dikembangkan berdasarkan prosedur pengembangan ilmiah meliputi uji kelayakan dan uji evaluasi multimedia pembelajaran. Kelayakan produk multimedia pembelajaran untuk mengembangan aspek kognitif berdasarkan hasil uji alpha dan uji beta diketahui sebagai berikut. Hasil uji alpha melalui validasi oleh ahli materi 1 diperoleh rata-rata penilaian 3,1 dengan kategori "Baik" dan validasi oleh materi 2 diperoleh rata-rata penilaian sebesar 3,7 dengan kategori "Sangat Baik".

Hasil uji alpha melalui validasi oleh ahli media 1 diperoleh rata-rata penilaian 
yakni 3,2 dengan kategori "Baik" dan validasi oleh ahli media 2 diperoleh ratarata penilaian 3,52 dengan kategori "Sangat Baik". Hasil uji beta melalui validasi oleh Head teacher diperoleh rata-rata penilaian sebesar 3,7 dengan kategori "Sangat Baik". Hasil evaluasi terhadap penggunaan multimedia pembelajaran untuk mengembangan aspek kognitif pada kelas K1 Pagi Palm Kids School Yogyakarta menunjukkan bahwa terdapat peningkatan pencapaian hasil perkembangan kognitif pada anak K1 pagi Palm Kids School dari nilai rata-rata pretest 6,1 meningkat pada post-test menjadi 8,7. Berdasarkan pemaparan tersebut tingkat kelayakan multimedia pembelajaran dikategorikan sangat baik. Melalui uji beta diketahui multimedia pembelajaran dapat meningkatkan perkembangan aspek kognitif anak K1 pagi Palm Kids School Yogyakarta.

Saran

Berdasarkan temuan hasil penelitian pada waktu uji coba dengan multimedia pembelajaran anak-anak terlihat lebih tertarik mengerjakan permainan yang ada di dalam multimedia pembelajaran daripada belajar dengan menu materi. Maka dari itu peneliti memberikan beberapa saran untuk guru pendamping atau orangtua yang akan mendapingi anak belajar dengan multimedia pembelajaran harus memberikan pengertian kepada anak bahwa menu permainan dapat digunakan setelah anak belajar dengan menu materi terlebih dahulu.

Anak-anak yang pertama kali belajar dengan multimedia pembelajaran sebaiknya perlu pendampingan guru/orang tua untuk membantu anak memberikan informasi cara menggunakan multimedia pembelajaran.

Multimedia Pembelajaran untuk mengembangan aspek kognitif ini perlu implementasi lebih lanjut pada sekolah taman kanak-kanak lainnya agar diketahui kebermanfaatannya dalam proses pembelajaran.
Materi mengenal bilangan yang terdapat pada multimedia pembelajaran untuk Mengembangan aspek kognitif perlu diperdalam pembahasannya agar anakanak yang menggunakan multimedia dapat mempelajari bilangan yang jumlahnya lebih besar dari bilangan 10 .

\section{Daftar Pustaka}

Alessi, S.M \& Trollip, S. R. (2001). Multimedia for learning, method and development, (3rd ed.). Massachusetts: Pearson Education Inc.

Deporter, B., Reardon, M., \& Singer, S. (2010) Quantum teaching mempraktikkan quantum learning di ruang-ruang kelas, Edisi baru (Terjemahan Ary Nilandari). Bandung: Kaifa.

Gallagher, P. K. (2010). The impact of learning style on learning outcomes in an interactive multimedia instruction (IMI) program. Disertasi, tidak diterbitkan, TUI University.

Januszewski, A \& Molenda, M. (2008). Educational technolgy a defintion with commentary. New York: Taylor and Francis Group.

Kalyuga, S., \& Tzu-Chien Liu. (2015). Managing cognitive load in technology-based learning environments, [Versi elektronik]. Journal of Educational Technology $\mathcal{E}$ Society, 4, (18), 1-8.

Menteri Pendidikan dan Kebudayaan. Peraturan Menteri Pendidikan dan Kebudayaan Republik Indonesia Nomor 137 Tahun 2014 tentang Standar Nasional Pendidikan Anak Usia Dini. (2014). Jakarta

Munir. (2013). Multimedia konsep \& aplikasi dalam pendidikan. Bandung: Alfabeta.

Phillips, R. (1997). The developers handbook to interactive multimedia (practical guide for educational application). USA: Kogan Page.

Putra, L. D. \& Ishartiwi. (2015). 
Pengembangan multimedia interaktif mengenal angka dan huruf untuk anak usia dini, [Versi elektronik]. Jurnal Inovasi Teknologi Pendidikan, 2, (2), 169-178.

Sugiyono. (2010). Statistika untuk penelitian. Bandung: Alfabeta.

Sukardjo. (2006). Kumpulan materi evaluasi pembelajaran. Yogyakarta: UNY Press.

Sulasmi. (2002). Warna teori dan kreativitas penggunaannya. Bandung: ITB

Trianto. (2011). Desain pengembangan pembelajaran tematik bagi anak usia dini TK/RA E anak usia kelas awal SD/MI. Jakarta: Kencana.
Tsung Juang Wang. (2012). Educational benefits of multimedia skills training. TechTrends, 1, (54), 47-60.

Wahyuningsih, M. (2011). Warna bisa mempengaruhi psikologis anak. Diakses pada tanggal 30 September 2016. Dari http:/ / health.detik.com/read/2011/0 4/14/120159/1617042/764/2/warnabisa-pengaruhi-psikologis-aNAK.

Wijaya, P. (2013). Perancangan buku ilustrasi anak berjudul kerajaan fantasi indonesia bertema gotong royong [Versi elektronik]. Student journal.petra.ac.id, 1, 689-789. 